\title{
Expression of Inducible Stress Protein 70 in Rat Heart Myogenic Cells Confers Protection against Simulated Ischemia-induced Injury
}

\author{
Ruben Mestril, Shun-Hua Chi, M. Richard Sayen, Kevin O'Reilly, and Wolfgang H. Dillmann \\ Department of Medicine, Division of Endocrinology \& Metabolism, University of California at San Diego, San Diego, California 92103
}

\begin{abstract}
Myocardial ischemia markedly increases the expression of several members of the stress / heat shock protein (HSP) family, especially the inducible HSP70 isoforms. Increased expression of HSP70 has been shown to exert a protective effect against a lethal heat shock. We have examined the possibility of using this resistance to a lethal heat shock as a protective effect against an ischemic-like stress in vitro using a rat embryonic heart-derived cell line H9c2(2-1). Myogenic cells in which the heat shock proteins have been induced by a previous heat shock are found to become resistant to a subsequent simulated ischemic stress. In addition, to address the question of how much does the presence of the HSP70 contribute to this protective effect, we have generated stably transfected cell lines overexpressing the human-inducible HSP70. Embryonal rat heartderived H9c2 (2-1) cells were used for this purpose. This stably transfected cell line was found to be significantly more resistant to an ischemic-like stress than control myogenic cells only expressing the selectable marker (neomycin) or the parental cell line H9c2(2-1). This finding implicates the inducible HSP70 protein as playing a major role in protecting cardiac cells against ischemic injury. (J. Clin. Invest. 1994. 93:759-767.) Key words: heat shock proteins • thermotolerance • myocardial ischemia $\bullet$ hypoxia
\end{abstract}

\section{Introduction}

Several studies have established that ischemia induces marked changes in the level of specific mRNAs and proteins in the myocardium, and some of the prominent proteins expressed during ischemia are members of the so-called heat shock or stress protein family (1-4). Our laboratory $(1,3)$, as well as others $(2,4)$, have shown that at least two members of the heat shock protein 70 (HSP70 $)^{1} \mathrm{kD}$ family of proteins are increased in their expression during ischemic damage in cardiac cells. The function of these heat shock proteins (HSPs) is mostly unknown, and only recently has it been found that the consti-

Address correspondence and reprint requests to Ruben Mestril, Ph.D., University of California at San Diego, 200 West Arbor Drive (8412), San Diego, CA 92013.

Received for publication 14 July 1993 and in revised form 27 September 1993

1. Abbreviations used in this paper: hHSP70, human heat shock protein; hHSPi, inducible human heat shock protein 70; HSP70i, inducible heat shock protein 70; NEO, neomycin; rHSP70i, rat-inducible heat shock protein $70 ; \mathrm{Rh} 123$, rhodamine 123 ; TK, thymidine kinase.

J. Clin. Invest.

(c) The American Society for Clinical Investigation, Inc. 0021-9738/94/02/0759/09 \$2.00

Volume 93, February 1994, 759-767 tutively expressed HSP70 in yeast cells seems to be an "unfoldase" that functions to facilitate the transport of proteins through the membranes of the endoplasmic reticulum and mitochondria $(5,6)$. It is widely believed that the HSPs have a protective function fitting with the observation that a short exposure to an elevated temperature $\left(42^{\circ} \mathrm{C}\right)$ confers heat resistance to cells subsequently exposed to a lethal heat shock $\left(45^{\circ} \mathrm{C}\right)$. This phenomenon is known as thermotolerance and has recently been demonstrated to be directly linked to the increased presence of inducible HSP70 isoforms in the cell (710). Depletion of HSP70 by microinjection of antibodies specific to HSP70 ( 7 ) or reduction in the expression of HSP70 by genetic means ( promoter competition) (8), decreased the cell's ability to withstand a severe heat shock. In addition, constitutive expression of an inducible HSP70 in mammalian cells has been found to confer heat resistance $(9,10)$. It is also interesting to note that a recent report has shown that pretreatment of rats with a mild heat shock $\left(15 \mathrm{~min}\right.$ at $42^{\circ} \mathrm{C}$ ) improved recovery from ischemia of perfused rat hearts by restoring contractility after reperfusion in a shorter time than in rat hearts that were not heat pretreated (4). Similarly, in rats submitted to heat shock $24 \mathrm{~h}$ earlier, a decrease in myocardial infarct size occurred in comparison to control animals (11). This would indicate that thermotolerance offers protection not only against a subsequent heat shock, but also against other stresses such as ischemia. It is then tempting to speculate that to the same degree with which HSP70 proteins protect the cell against lethal heat shock, it may also have the same protective function in the heart during ischemia of the myocardium.

Myocardial ischemia from a cellular point of view is composed of a diversity of factors that contribute to the severe stress. Among these stressors, one finds oxygen deprivation, ATP depletion, $\mathrm{Ca}^{2+}$ influx, glucose deprivation, accumulation of toxic metabolites, decrease in cellular $\mathrm{pH}$, and other changes. Recently, we have found that several of the these alterations caused by ischemia will also induce the expression of the HSP70 family of proteins in rat neonatal cardiac myocytes (12) and in a rat embryonic heart cell line H9c2(2-1). Given the strong HSP70 response to ischemia-related events, it is of great interest to examine the potential protective role of the HSP70 in cardiac cells under stress in vitro. In the present study, we have explored the protective effect conferred by a pre-heat treatment to $\mathrm{H} 9 \mathrm{c} 2(2-1)$ cells against simulated ischemia in vitro. Our studies show that a pre-heat shock improves the survival of the cells to a subsequent ischemia-like stress. In addition, we have generated several $\mathrm{H} 9 \mathrm{c} 2(2-1)$ cell lines stably transfected with the human-inducible HSP70 gene (13) under the transcriptional control of a simian virus 40 (SV40) enhancer-thymidine kinase (TK) promoter. One of these stably transfected H9c2(2-1) cell lines that was found to overexpress the human HSP70 was found to be significantly more resistant to our simulated ischemia conditions as compared to the parental H9c2(2-1) cells or cells expressing only the selectable 
marker (neomycin) gene. This leads us to conclude that at least part of the protective effect caused by pre-heat treatment against a subsequent ischemia-like stress is attributable to the increased presence of the HSP70.

\section{Methods}

Cell culture and transfection. The embryonic rat heart-derived cell line H9c2(2-1) was obtained from the American Type Culture Collection (CRL-1446; ATCC, Rockville, MD). The cells were maintained in DME supplemented with antibiotics (penicillin/streptomycin/fungizone; Gibco Laboratories, Grand Island, NY) and 10\% FCS. Heat shock treatment of the $\mathrm{H} 9 \mathrm{c} 2(2-1)$ cells was done by floating a sealed culture dish $(10 \mathrm{~cm})$ in a $42^{\circ} \mathrm{C}$ water bath for $30 \mathrm{~min}$ and returned to $37^{\circ} \mathrm{C}$ for $8 \mathrm{~h}$ before any further treatment. Simulated ischemia was achieved by placing the cells in slightly hypotonic HBSS $1.3 \mathrm{mM}$ $\mathrm{CaCl}_{2}, 5 \mathrm{mM} \mathrm{KCl}, 0.3 \mathrm{mM} \mathrm{KH}_{2} \mathrm{PO}_{4}, 0.5 \mathrm{mM} \mathrm{MgCl}_{2}, 0.4 \mathrm{mM} \mathrm{MgSO}_{4}$, $69 \mathrm{mM} \mathrm{NaCl}, 4 \mathrm{mM} \mathrm{NaHCO}$, and $0.3 \mathrm{mM} \mathrm{Na}_{2} \mathrm{HPO}_{4}$ without glucose or serum, and made hypoxic for $4-6 \mathrm{~h}$ at $37^{\circ} \mathrm{C}$, while control cells were left in HBSS under normoxic conditions at $37^{\circ} \mathrm{C}$. Hypoxia was achieved by using an air-tight jar from which $\mathrm{O}_{2}$ was removed by replacement with argon. After 10 min of gas exchange, the $\mathrm{O}_{2}$ concentration in the jar was $<0.2 \%$. For maintenance of hypoxia, the $\mathrm{O}_{2}$ consuming GasPak System from BBL Microbiology Systems (Cockeysville, MD) was used (14).

Stably transfected H9c2(2-1) cell lines were obtained by transfecting subconfluent H9c2(2-1) cells by a modified calcium-phosphate transfection protocol (15). Culture dishes of subconfluent H9c2(2-1) were transfected with $5 \mu \mathrm{g}$ of pMC1 / NEO poly(A) (Stratagene Inc., La Jolla, CA), which contains the selectable marker gene, neomycin (NEO), under the control of the herpes simplex TK promoter, enhancer sequences from the polyoma virus Py F441, and $15 \mu \mathrm{g}$ of either pSVTK-human HSP70 (hHSP70) which contains the human-inducible HSP70 (hHSP70i) gene, kindly provided by Dr. Richard Morimoto (Northwestern University, Evanston, IL) (13), under the control of TK promoter and the SV40 enhancer to generate the H9/hHSP70 clonal lines. In addition, $\mathrm{H} 9 \mathrm{c} 2(2-1)$ cells were transfected with $5 \mu \mathrm{g}$ of $\mathrm{pMCl} / \mathrm{NEO}$ poly (A) and $15 \mu \mathrm{g}$ of the vector pUC18 to generate the control $\mathrm{H} 9 / \mathrm{NEO}$ clonal cell line. $48 \mathrm{~h}$ after transfection, the $\mathrm{H} 9 \mathrm{c} 2$ (21) cells were trypsinized and replated in DME, $10 \% \mathrm{FCS}$, and the selective neomycin analogue $\mathrm{G} 418$-sulfate $(400 \mu \mathrm{g} / \mathrm{ml})$. Selection was carried out for $4 \mathrm{wk}$ with media changes every $3 \mathrm{~d}$. Colonies derived from a single surviving cells were isolated and propagated as stably transfected single cell colony cell lines, while the remaining cells that were not isolated were pooled and propagated as stably transfected pooled cell lines in media containing maintenance amounts of G418sulfate $(200 \mu \mathrm{g} / \mathrm{ml})$. Numerous aliquots of the stably transfected cell lines were frozen down in liquid $\mathrm{N}_{2}$. All experiments were performed on stably transfected cell lines between 3 and 10 passages after being thawed out. H9c2(2-1) cells used as controls were of equivalent passage numbers as the stably transfected cell line. The doubling times of the different cell lines used were 25,28 , and $24 \mathrm{~h}$ for H9c2(2-1), H9/ hHSP70/1, and H9/NEO, respectively.

RNA analysis. Total RNA from H9c2(2-1) and stably transfected $\mathrm{H} 9 \mathrm{c} 2(2-1)$ cell lines were prepared by the guanidine- $\mathrm{HCl}$ method (16). Northern blot analysis was done on $10 \mu \mathrm{g}$ of total RNA of each sample, which were fractionated on a $1 \%$ formaldehyde-agarose gel, blotted on to a nylon membrane (Nytran), and subsequently hybridized with a DNA fragment containing the hHSP70 gene using standard methods (17). The DNA was labeled using $\left[\alpha^{32} \mathrm{P}\right]-\mathrm{dCTP}$ and the multiprime DNA labeling system (Amersham Corp., Arlington Heights, IL). Northerns were hybridized at $42^{\circ} \mathrm{C}$ overnight and subsequently washed with $2 \times \mathrm{SSC}, 0.1 \% \mathrm{SDS}$ at $55^{\circ} \mathrm{C}$, and exposed to $\mathrm{x}$-ray film for $14-16 \mathrm{~h}$. The results shown are representative of three separate Northern analysis experiments that yielded similar results.

Protein analysis. Cellular protein extracts were prepared from H9c2(2-1) and the stably transfected cell lines after heat shock or they were left untreated. The soluble protein fraction was prepared by washing the cells twice with ice-cold PBS, cells were then scraped with a silicone rubber policeman in $1 \mathrm{ml}$ of PBS, centrifuged at $1,000 \mathrm{~g}$, and pellet resuspended in $200 \mu \mathrm{l}$ of protein extraction buffer $(50 \mathrm{mM}$ Hepes, $\mathrm{pH}$ 7.4, 1 mM EDTA, $1 \mathrm{mM}$ 2-mercaptoethanol, $1 \mathrm{mM}$ PMSF, $2 \mu \mathrm{g} / \mathrm{ml}$ leupeptin, and $1 \mu \mathrm{g} / \mathrm{ml}$ pepstatin). Soluble proteins were obtained by four cycles of freeze $\left(-70^{\circ} \mathrm{C}\right)$ and thaw $\left(37^{\circ} \mathrm{C}\right)$, after which cell suspension was centrifuged at $12,000 \mathrm{~g}$, where supernatant constituted our soluble protein fraction. The remaining pellet was resuspended in solution B (18) containing $1 \%$ Triton and $0.5 \%$ deoxycholate, vortexed, and left on ice $15 \mathrm{~min}$, centrifuged at $12,000 \mathrm{~g}$ for 15 min, and the supernatant constituted our insoluble protein fraction. Protein concentration was determined by the Bradford Assay (Bio-Rad Laboratories, Richmond, CA).

Protein samples ( $40 \mu \mathrm{g}$ each) were fractionated on a $8 \%$ SDS-polyacrylamide gel and electrotransferred onto nitrocellulose using a semidry electrotransfer apparatus (Bio-Rad Laboratories). The nitrocellulose blots were reacted with a monoclonal antibody C92F3A-5 (Stress Gen; Biotechnologies Corp, Victoria, BC), which binds specifically to all the mammalian-inducible HSP70, and Western blots were reacted with an anti-mouse IgG biotin-streptavidin, horseradish peroxidaseconjugated system (Vectastain, ABC kit; Vector Laboratories, Burlingame, CA) and developed with diaminobenzidine tetrahydrochloride (DAB kit; Vector Laboratories). Immunoprecipitation experiments were done by exposing subconfluent $6-\mathrm{cm}$ culture plates of $\mathrm{H} 9 \mathrm{c} 2(2-1)$ cells to heat shock $\left(42^{\circ} \mathrm{C}\right.$ for $30 \mathrm{~min}$ ) and then returned to $37^{\circ} \mathrm{C}$ for 2 , 4,6 and $8 \mathrm{~h}$. The H9c2 (2-1) cells were metabolically labeled during the final $2 \mathrm{~h}$ at $37^{\circ} \mathrm{C}$ in $1 \mathrm{ml}$ of DME deficient in cystine, methionine, and cysteine (ICN Biochemicals, Inc., Costa Mesa, CA) containing $100 \mu \mathrm{Ci}$ of $\left[{ }^{35} \mathrm{~S}\right]$ methionine ( Trans ${ }^{35} \mathrm{~S}$-label; ICN Biochemicals, Inc.). Cellular protein extracts were prepared as described before and the amount of TCA-precipitable cpm determined on the soluble protein fraction. Immunoprecipitation was carried out as previously described (12) on $10^{6}$ TCA-precipitable cpm of each sample, using a polyclonal antiserum raised against a synthetic peptide identical to the $\mathrm{COOH}$ terminal of the mammalian HSP70s and HSP90s (3). The resulting immunoprecipitated proteins were fractionated on a $8 \%$ SDS-polyacrylamide gel, fixed, enhanced, dried, and exposed to x-ray film for 14-16 h.

Analytical techniques. Cellular injury by our simulated ischemia protocol was scored by the mitochondria-specific fluorescent dye rhodamine 123 (Rh123). Retention of the $\mathrm{Rh} 123^{1}$ was measured both by immunofluorescence and flow cytometry. Cells were plated either on 10-cm culture dishes for flow cytometry or on chamber slides (Lab Tek Chamber slides; Nunc, Inc., Naperville, IL) for immunofluorescence. Pre-heat treated and cells that were not pretreated were exposed to $\mathrm{Rh} 123(25 \mu \mathrm{M})$ added directly to the media for $30 \mathrm{~min}$, after which both plates and slides were washed several times to remove any free $\mathrm{Rh} 123$. Plates and slides were then either submitted to simulated ischemia or left untreated at $37^{\circ} \mathrm{C}$ under normoxic conditions as controls. Subsequently, the cells in the culture dishes were trypsinized, centrifuged, and resuspended in media at a concentration of $10^{6} \mathrm{cells} / \mathrm{ml}$ and analyzed by flow cytometry (450-560 $\mathrm{nm}$ using argon ion laser illumination) to determine the amount of $\mathrm{Rh} 123$ leaked in cells made ischemic as compared to cells that were untreated. Cells on chamber slides were analyzed by fluorescent microscopy to assess visual leakage of the dye from the cells.

Immunohistochemistry to visualize the expression of the inducible HSP70 was done on H9c2 (2-1) cells and stably transfected cell lines that were plated on chamber slides (Lab Tek). Chamber slides were either heat shocked $\left(42^{\circ} \mathrm{C}, 1 \mathrm{~h}\right)$ or left untreated. After heat shock, slides were left to recuperate at $37^{\circ} \mathrm{C}$ for $2 \mathrm{~h}$. Cells were then washed with PBS and fixed with cold methanol $\left(-20^{\circ} \mathrm{C}\right)$ for $2 \mathrm{~min}$. Slides were then treated with PBS containing $0.1 \%$ bovine serum albumin (fraction V; Sigma Immunochemicals, St. Louis, MO) and $1 \%$ mouse whole serum for $15 \mathrm{~min}$ at room temperature. Slides were then reacted with the monoclonal antibody C92F3A-5 (StressGen), which binds to the inducible form of HSP70 for $60 \mathrm{~min}$. Slides were washed three times and further developed with an anti-mouse IgG, biotin-streptavidin- 
conjugated horseradish peroxidase system (Vectastain $\mathrm{ABC}$ kit) and DAB substrate kit (Vector Laboratories).

Colony survival assays were done by trypsinizing the cells maintained under simulated ischemic or control conditions. Cells were collected by centrifugation at $400 \mathrm{~g}$, resuspending the pellet in a small volume of media and determining cell density using a hemocytometer on an aliquot. The remainder of the cells were serially diluted and replated, in duplicate, at a density of $2.5 \mathrm{cells} / \mathrm{cm}_{2}$ in $10-\mathrm{cm}$ culture dishes and returned to $37^{\circ} \mathrm{C}$ for 7-9 d. Plates were then fixed and stained with $0.5 \%$ methylene blue in methanol/water (1:1). The number of single cell colonies formed (colonies with a minimum of 50 cells) at the end of this period of time were counted. Cell survival is defined as the ratio of colonies formed by the initially plated cells and normalized to the plating efficiency. Plating efficiencies were 50-65, 48-55, and 48-57\% for H9c2(2-1), H9/NEO, and H9/hHSP70/1, respectively.
Lactate dehydrogenase (LDH) released from ischemic and normoxic cells was determined by an LDH test kit (Sigma Immunochemicals) and following the manufacturers recommendations.

Statistical analysis. Results are expressed as mean \pm SE. Statistical significance was assessed by analysis of variance followed by a Bonferroni f test.

\section{Results}

Initially, we determined if submitting the myogenic cell line H9c2(2-1) to a heat shock $\left(42^{\circ} \mathrm{C}\right)$ for 30 min could confer resistance against a subsequent simulated ischemic stress. Preheat treated and untreated $\mathrm{H} 9 \mathrm{c} 2(2-1)$ cells were submitted to simulated ischemia after an 8 -h period of recovery at $37^{\circ} \mathrm{C}$.
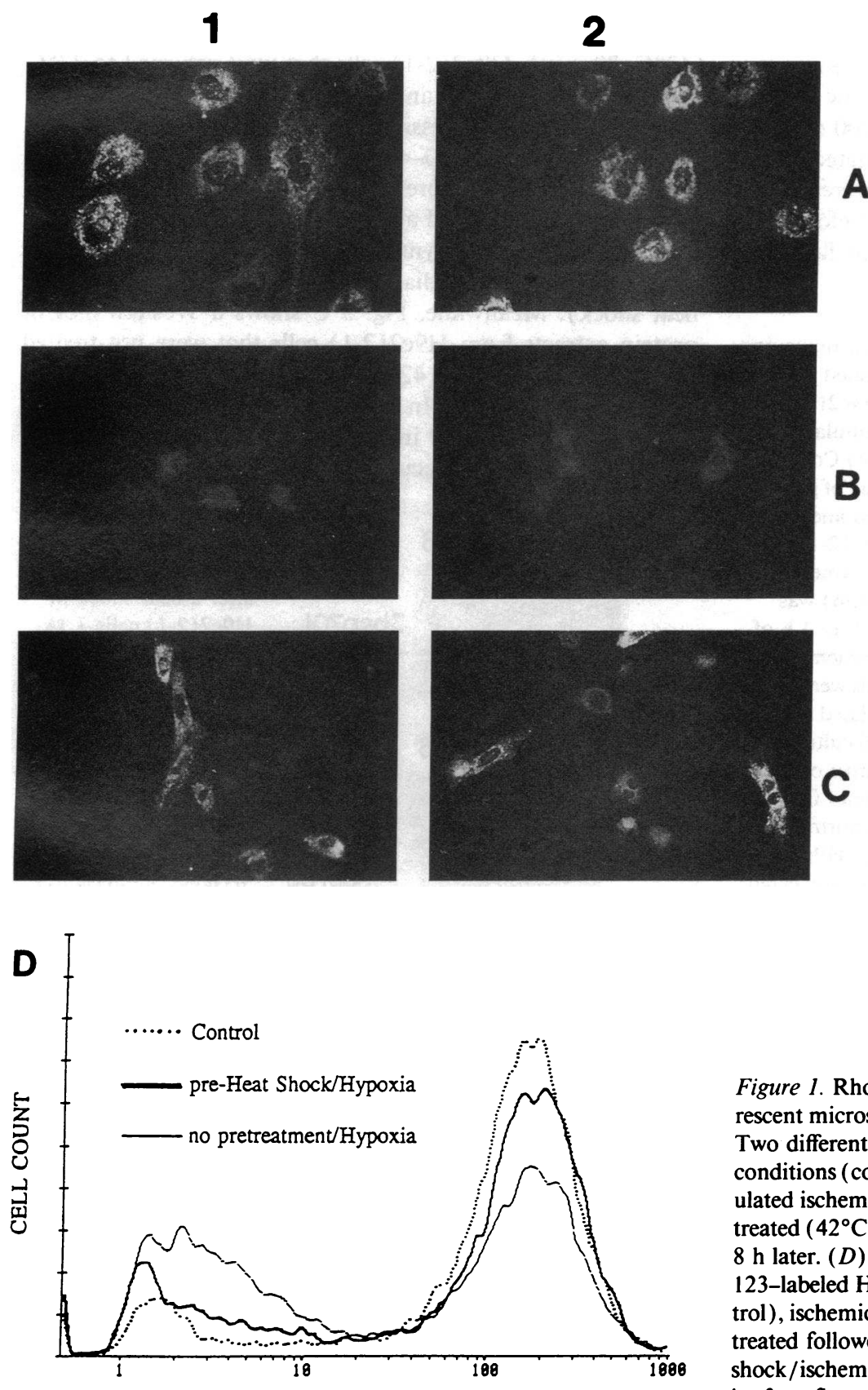

FLUORESCENCE

Figure 1. Rhodamine 123 retention after simulated ischemia. Fluorescent microscopy of rhodamine 123-labeled H9c2(2-1) cells. $(A)$ Two different slides ( $I$ and 2 ) of $\mathrm{H} 9 \mathrm{c} 2(2-1)$ submitted to normoxic conditions ( control ). (B) Two slides of H9c2(2-1) submitted to simulated ischemia. $(C)$ Two slides of H9c2(2-1) cells that were preheat treated $\left(42^{\circ} \mathrm{C}, 30 \mathrm{~min}\right)$ before being submitted to simulated ischemia $8 \mathrm{~h}$ later. $(D)$ Fluorescence recordings obtained from Rhodamine 123-labeled H9c2 (2-1) cells submitted to normoxic conditions (control), ischemic conditions (no pretreatment/ischemia), and pre-heat treated followed by ischemic conditions $8 \mathrm{~h}$ later (pre-heat shock/ischemia). Fluorescence scale is logarithmic. The peak at $\sim 2$ is of nonfluorescent cells and the peak at $\sim 200$ is of fluorescent cells. Control cells are taken as $100 \%$ of possible fluorescence. 
Simulated ischemia consisted of hypoxia $\left(\mathrm{O}_{2}\right.$ deprivation $)$, in the absence of glucose to resemble lack of nutrients, low volume incubation to mimic the absence of washout and hypotonicity of the medium to resemble the lower tonicity of the extracellular milieu in comparison to the tonicity of the myocytes. We used retention of the fluorescent dye rhodamine 123, which has been well established as a reliable measurement of cellular damage $(19,20)$. H9c2(2-1) cells were loaded with Rh123 (25 $\mu \mathrm{M})$ for 30 min before being submitted to simulated ischemic conditions or left untreated. Fig. $1 A$ shows two separate slides of the normal fluorescence obtained with $\mathrm{Rh} 123$ in $\mathrm{H} 9 \mathrm{c} 2(2-1)$, which have been left untreated. Fig. $1 B$ shows the decrease of fluorescence caused by leakage of $\mathrm{Rh} 123$ from the H9c2 (2-1) cells after simulated ischemia. Fig. $1 C$ presents the results obtained when pre-heat treated cells were submitted to simulated ischemia where the majority of the cells have retained most of the Rh123 after ischemic stress. Fig. $1 D$ shows the fluorescent histogram obtained by flow cytometry on these cells. Control H9c2(2-1) cells were untreated and show a majority of the cells with a high level of fluorescence ( 200 on the fluorescence scale). Cells that were submitted to simulated ischemia without a pre-heat treatment show a $35 \%$ decrease in fluorescence, while cells that were pre-heat shocked before the simulated ischemia present only a $12 \%$ decrease in fluores-

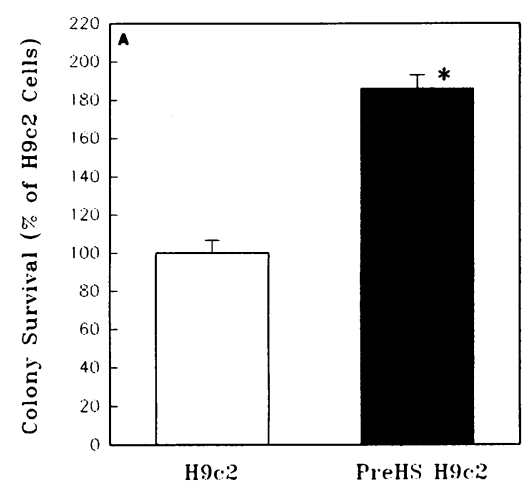

Figure 2. Cell injury in pre-heat treated and untreated $\mathrm{H} 9 \mathrm{c} 2(2-1)$ cells after simulated ischemia. $(A)$ Colony survival assay of preheat-shocked and untreated H9c2 (2-1) cells. Pre-heat treatment $\left(42^{\circ} \mathrm{C}, 30 \mathrm{~min}\right)$ was done $8 \mathrm{~h}$ before $4 \mathrm{~h}$ of simulated ischemic conditions. Cells were trypsinized, replated at low density, and cultured for 7-9 d. Number of sur-

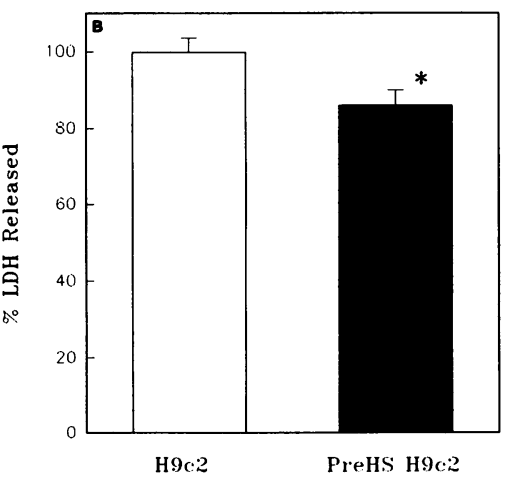
viving colonies for each group were normalized to untreated $\mathrm{H} 9 \mathrm{c} 2(2-1)$ cells. $\square$, Non-preheated H9c2(2-1) cells submitted to simulated ischemia taken as $100 \%$ of possible surviving colonies; $\approx$, H9c2(2-1) preheated and subsequently submitted to simulated ischemia expressed as a percentage

of non-pretreated $\mathrm{H} 9 \mathrm{c} 2(2-1)$ cells. Results are from six independent experiments $\left({ }^{*} P<0.01\right)$. ( $\left.B\right) \mathrm{LDH}$ release of pre-heat-shocked and untreated $\mathrm{H} 9 \mathrm{c} 2(2-1)$ cells. Results are expressed as percentage of LDH released over total LDH (released + cellular LDH) for each sample and then normalized to the amount of LDH released by control H9c2(2-1) cells. $\square$, LDH released by $\mathrm{H} 9 \mathrm{c} 2(2-1)$ cells made ischemic without pretreatment and taken as $100 \%$ of LDH release; $\boldsymbol{m}$, $\mathrm{LDH}$ released by $\mathrm{H} 9 \mathrm{c} 2(2-1)$ pre-heat treated and subsequently made ischemic and as a percentage of non-pretreated $\mathrm{H} 9 \mathrm{c} 2(2-1)$ cells. Results are from seven independent experiments $\left({ }^{*} P<0.05\right)$. cence. These results indicate that a pre-heat treatment confers a certain amount of resistance to a subsequent ischemic stress.

To corroborate these results by more conventional methods, we submitted H9c2(2-1) cells to the same procedure of simulated ischemia with and without a pre-heat shock and measured cell survival by using a colony survival assay and cell injury by measuring lactate dehydrogenase release after an ischemic stress. Fig. 2 shows the results of the colony survival assay where the pre-heat-shocked cells exhibited better survival than cells that were not pre-heat-shocked (Fig. $2 \mathrm{~A}$ ). In addition, the results of the LDH release assay show that the pre-heatshocked cells also have an advantage against cell injury during ischemic stress (Fig. $2 \mathrm{~B}$ ).

Since the HSP70 is the most abundant of the heat shock proteins, we examined the expression and accumulation of HSP70 in H9c2(2-1) cells after a heat shock. Fig. $3 A$ shows a representative Northern blot of total RNA from heat-shocked $\left(42^{\circ} \mathrm{C}, 30 \mathrm{~min}\right), \mathrm{H} 9 \mathrm{c} 2(2-1)$ cells that were returned to $37^{\circ} \mathrm{C}$ for a period of $0,2,4,6$, and $8 \mathrm{~h}$ or not heat treated (control). As can be observed, expression of HSP70i mRNA occurs immediately after heat shock ( $0-4 \mathrm{~h}$ after heat shock). Fig. $3 B$ shows the result of an immunoprecipitation experiment that corroborates the results obtained at the mRNA level. The increase in the relative protein synthesis rate of inducible HSP70 (HSP70i) occurs immediately after heat shock (0-6 h after heat shock). Meanwhile, Fig. $3 C$ shows a Western blot of protein extracts from $\mathrm{H} 9 \mathrm{c} 2(2-1)$ cells that were not treated (control), heat shocked $\left(42^{\circ} \mathrm{C}, 30 \mathrm{~min}\right)$, and returned to $37^{\circ} \mathrm{C}$ for $0,2,4,6$, and $8 \mathrm{~h}$. In this case, we can observe that the HSP70i starts to appear in $\mathrm{H} 9 \mathrm{c} 2(2-1)$ cells at $2 \mathrm{~h}$ after heat shock and continues to accumulate in subsequent hours. There-

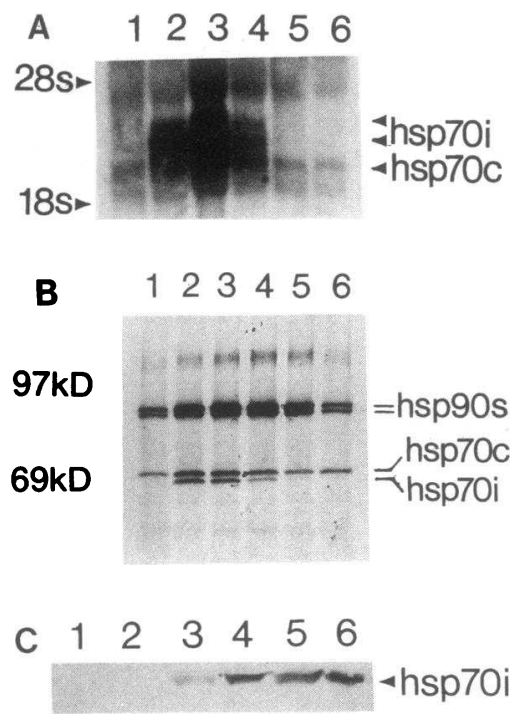

Figure 3. Synthesis and accumulation of HSP70 after a heat shock in H9c2(2-1) cells. $(A)$ Northern blot analysis of total RNA ( $10 \mu \mathrm{g}$ of each) from $\mathrm{H} 9 \mathrm{c} 2(2-1)$ cells that were left untreated $\left(37^{\circ} \mathrm{C}\right)($ lane 1$)$, heat shock $\left(42^{\circ} \mathrm{C}, 30\right.$ $\mathrm{min})$ and returned to $37^{\circ} \mathrm{C}$ for $0 \mathrm{~h}$ (lane 2 ), 2 h (lane 3), 4 h (lane 4), $6 \mathrm{~h}$ (lane 5 ), and $8 \mathrm{~h}$ (lane 6). Blot was probed with the human-inducible HSP70 gene that hybridizes to both rat-inducible HSP70 mRNAs and the constitutive HSP70

mRNA. (B) Immunoprecipitation of H9c2(2-1) newly synthesized proteins labeled with $\left[{ }^{35} \mathrm{~S}\right.$ ] methionine during the last $2 \mathrm{~h}$ of incubation after no treatment $\left(37^{\circ} \mathrm{C}\right)$ (lanes 1 and 6$)$, heat shock $\left(42^{\circ} \mathrm{C}, 30\right.$ $\mathrm{min}$ ) and $2 \mathrm{~h}$ (lane 2), $4 \mathrm{~h}$ (lane 3 ), $6 \mathrm{~h}$ (lane 4 ), and $8 \mathrm{~h}$ (lane 5 ) of recovery at $37^{\circ} \mathrm{C}$. The position of the inducible and constitutive HSP70, as well as the HSP90s, which are also recognized by the rabbit antisera used ( 3 ) are indicated. $(C)$ Western blot analyses of protein extracts ( $40 \mu \mathrm{g}$ in each lane) from $\mathrm{H} 9 \mathrm{c} 2(2-1) \mathrm{kept}$ at $37^{\circ} \mathrm{C}$ (lane 1$)$; heat shocked $\left(42^{\circ} \mathrm{C}, 30 \mathrm{~min}\right.$ ) and returned to $37^{\circ} \mathrm{C}$ for $0 \mathrm{~h}$ (lane 2); $2 \mathrm{~h}$ (lane 3); $4 \mathrm{~h}$ (lane 4); $6 \mathrm{~h}$ (lane 5), and $8 \mathrm{~h}$ (lane 6). Blot was reacted with the inducible HSP70-specific antibody C92F3A-5. 
fore, at $8 \mathrm{~h}$ after heat shock, the level of HSP70i is high in H9c2(2-1) cells and correlates with the observed protective effect against simulated ischemia.

These experiments encouraged us to generate stably transfected H9c2 (2-1) cell lines containing exogenous copies of the hHSP70 (13). H9c2(2-1) cells were transfected with pMC1/ NEO poly (A) alone or with both $\mathrm{pMC1} / \mathrm{NEO}$ poly(A) and $\mathrm{pSV} / \mathrm{TK} / \mathrm{hHSP70}$. The latter plasmid contains the hHSP70 gene under the control of a SV40 enhancer-TK promoter. Cells were selected with the neomycin analogue G418-sulfate for $4 \mathrm{wk}$, and single-cell colonies and pooled cell lines were obtained as described in Methods. The cell lines generated were characterized by Northern blot analysis. Fig. 4 shows a representative Northern blot with total RNA form the different cell lines and probed with the hHSP70 cDNA, which hybridizes to the human, as well as the rat-inducible and constitutive forms of the HSP70. The exogenous hHSP70 gene generates a larger size mRNA than the endogenous rat HSP70s as can be seen for the single-cell colony cell line $\mathrm{H} 9 / \mathrm{hHSP} 70 / 1$, which was found to overexpress significant amounts of the hHSP70.

In an effort to confirm that the exogenous hHSP70 mRNA is translated into protein in cell line $\mathrm{H} 9 / \mathrm{hHSP70} / \mathrm{l}$, we analyzed the levels of HSP70 at the protein level by Western blots and immunohistochemistry using an antibody specific for the inducible form of HSP70. Fig. $5 \mathrm{~A}$ shows a Western blot with soluble protein extracts from the stably transfected, as well as the parental H9c2(2-1) cells that were either heat shocked and processed immediately, so as to not permit translation of the induced endogenous HSP70 mRNA or were left untreated. As can be observed, the specific antibody only gives a signal for the hHSP70 in lanes containing protein extracts from the $\mathrm{H9} /$ hHSP70/ 1 cell line. Fig. $5 B$ shows a similar Western blot, but in this case, cells were heat shocked $\left(42^{\circ} \mathrm{C}, 60 \mathrm{~min}\right)$ and then permitted to recover at $37^{\circ} \mathrm{C}$ for $4 \mathrm{~h}$ so as to permit protein translation of the induced endogenous HSP70 mRNA. As can be observed, the antibody recognizes in the heat shock lanes the presence of the endogenous rat HSP70 protein. Fig. 6 shows the results of immunohistochemistry on both the H9/hHSP70/1

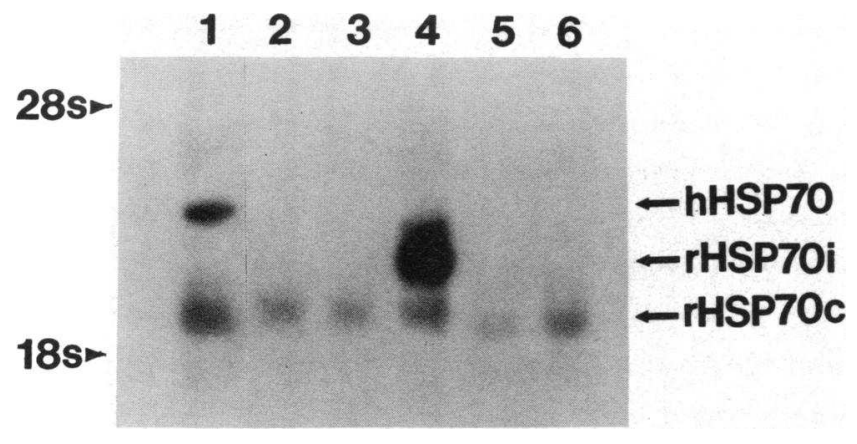

Figure 4. RNA analysis of stably transfected H9c2(2-1) cell lines. Representative Northern blot analysis of total RNA ( $10 \mu \mathrm{g}$ of each sample) of the stably transfected cell lines and parental H9c2(2-1) cells. Lane 1, RNA from $\mathrm{H} 9 / \mathrm{hHSP70/1}$; lane 2, H9/hHSP70/11 cell line; lane 3, H9/NEO cells; lane 4, heat-shocked parental H9c2 (2-1) cells; lane 5, untreated H9c2 (2-1) cells; lane 6, H9/hHSP70p (pooled stably transfected cell line). The signal from the exogenous human HSP70 and the rat-inducible (rHSP70i) and constitutive forms of HSP70 are indicated. The position of the ribosomal RNA 28S and $18 \mathrm{~S}$ are also indicated. Significant amounts of hHSP70 mRNA occur only in H9/hHSP70/ 1 cells.
A

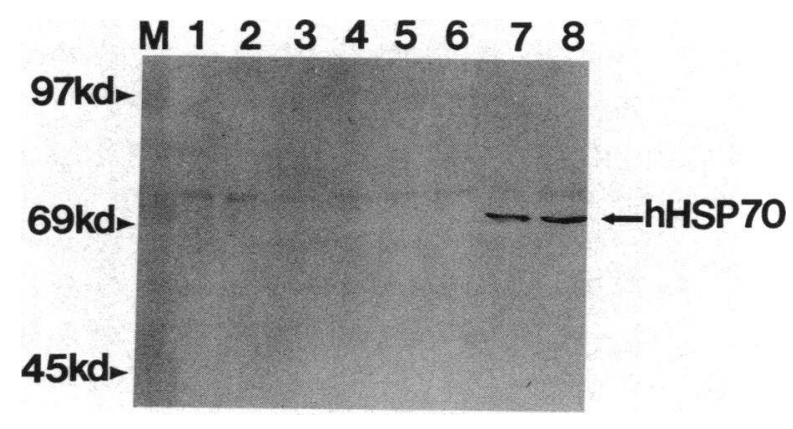

B

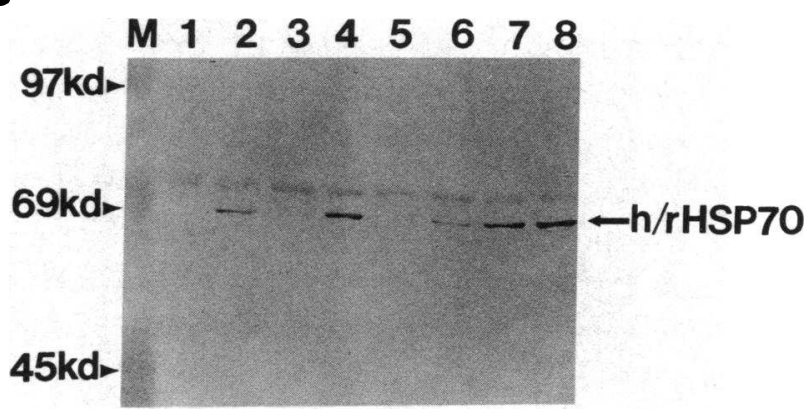

Figure 5. Western blot analysis of stably transfected H9c2(2-1) cell lines. Protein samples ( $40 \mu \mathrm{g}$ of each sample) were separated by $8 \%$ SDS-PAGE, electrotransferred to nitrocellulose, and subsequently reacted with the inducible HSP70-specific antibody C92F3A-5. $(A)$ Processed immediately after heat shock: lanes 1 and 2 , parental H9c2(2-1) cells; lanes 3 and 4, H9/NEO cell lines; lanes 5 and 6 , $\mathrm{H} 9 / \mathrm{hHSP} 70 / 11$ cell line; lanes 7 and $8, \mathrm{H} 9 / \mathrm{hHSP} 70 / 1$ cell lines. $(B)$ Processed after $4 \mathrm{~h}$ of recovery at $37^{\circ} \mathrm{C}$ after the heat shock. The position of the inducible HSP70 human and HSP70 rat is shown, as well as position of prestained molecular weight size markers. Lanes 1,3 , 5 , and 7 are from untreated cells; lanes 2, 4, 6, and 8 are from cells heat shocked at $42^{\circ} \mathrm{C}$ for $60 \mathrm{~min}$. In cells processed immediately after heat shock, which does not allow for HSP70 formation from the endogenous rHSP70i gene, hHSP70 is only detectable in $\mathrm{H} 9 / \mathrm{hHSP70} / 1$ cells.

cell line and the parental H9c2(2-1) cells before (Fig. 6, $A$ and $C$ ) and after heat shock (Fig. $6 B$ and $D$ ). Under normal conditions, a high amount of exogenous hHSP70 is present in the cytoplasm of the H9/hHSP70/1 cells (Fig. $6 \mathrm{~A}$ ) (seen as a brown coloration throughout cytoplasm), but not in the parental H9c2 (2-1) cells (Fig. $6 C$ ). After a heat shock $\left(42^{\circ} \mathrm{C}, 1 \mathrm{~h}\right)$ and $2 \mathrm{~h}$ of recovery, the majority of the hHSP70 (Fig. $6 \mathrm{~B}$ ), as well as the induced rat HSP70 (Fig. $6 D$ ) are localized in the vicinity of the nucleus of the cell (seen as brown coloration in and around nucleus), which is the normal site of relocalization of the HSP70 in the cell under stress (21). These results demonstrate that cell line H9/hHSP70/1 overexpresses significant amounts of functional hHSP70.

To assess how the overexpression of the hHSP70 contributes to the protection against ischemic stress, we compared cell survival and cellular injury in $\mathrm{H} 9 / \mathrm{hHSP70} / 1$ cell line, as well as the $\mathrm{H} 9 / \mathrm{NEO}$ and parental $\mathrm{H} 9 \mathrm{c} 2(2-1)$ cells after simulated ischemia. Fig. $7 A$ shows the results obtained from the colony 

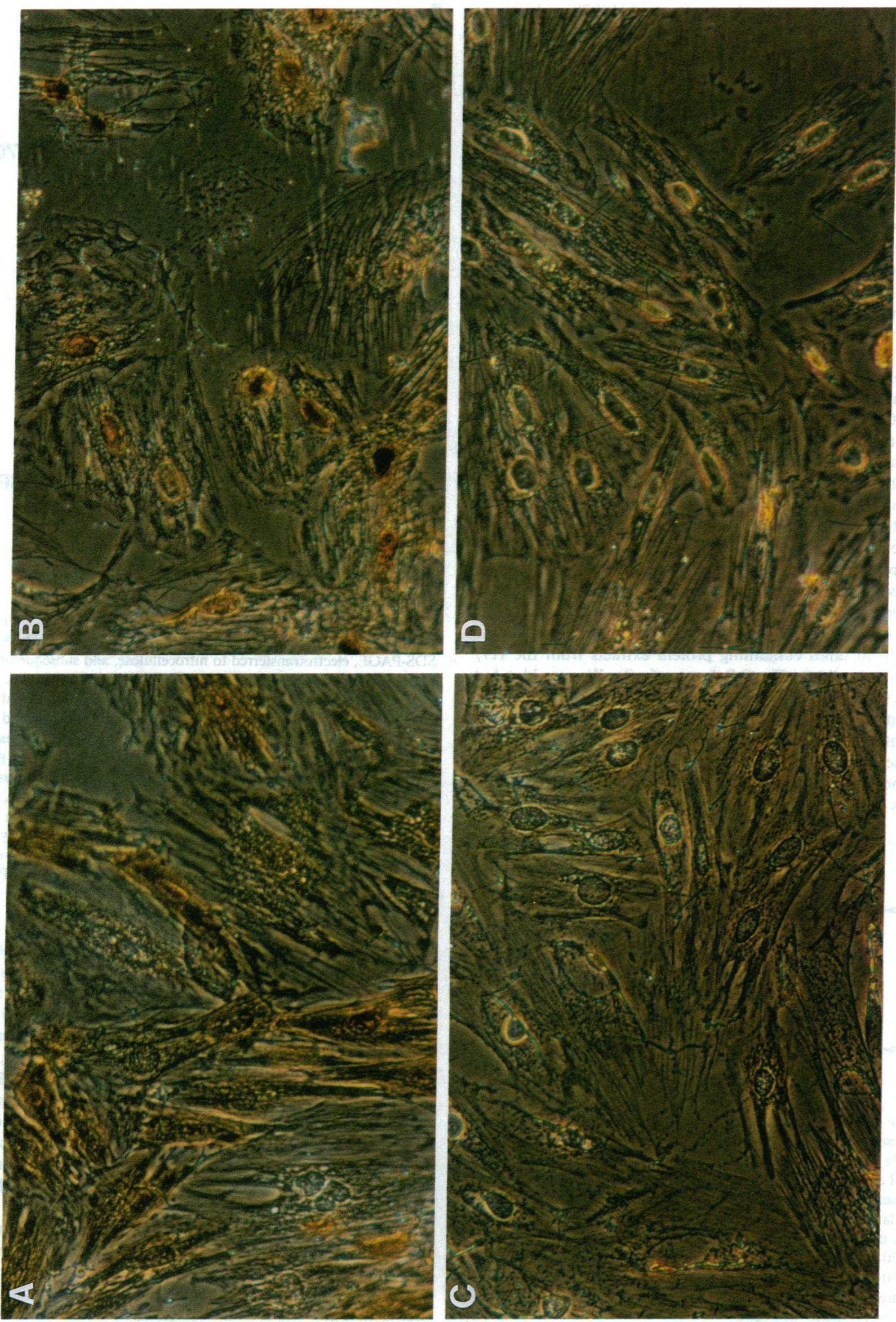
survival assay after a 6 -h simulated ischemia. Fig. $7 B$ shows how simulated ischemia caused cellular injury to the different cell lines as measured by LDH release assay. In both the colony survival and LDH release assays, the cell line H9/hHSP70/ 1 exhibited an increased resistance to the ischemic stress as compared to both the control cell line H9/NEO and the parental H9c2(2-1).

Recent reports have shown that HSP70 interacts with the heat shock factor, which controls the transcription of all of the heat shock genes $(22,23)$. Therefore, it is possible that the overexpression of the human HSP70 in the rat H9c2(2-1) cells may affect the expression of other heat shock proteins that could then be responsible for the increased survival of the $\mathrm{H} 9$ / hHSP70/1 cell line to ischemic injury. We tested this possibility by examining the expression of HSP90 and HSP27 mRNA on Northern blots containing total RNA from H9c2(2-1), H9/ NEO, and $\mathrm{H} 9 / \mathrm{hHSP} 70 / 1$ cell lines and using cDNA probes for the HSP90 and HSP27, kindly provided by Dr. Lee A. Weber (University of Nevada, Reno, NV) (24). Our results showed no significant change in the expression of either the rat HSP90 or HSP27 in the human HSP70 overexpressing cell line $\mathrm{H} 9 / \mathrm{hHSP} 70 / 1$ as compared to the neomycin-expressing cell line $\mathrm{H} 9 / \mathrm{NEO}$ or the parental H9c2(2-1) cell line (data not shown).

\section{Discussion}

The incidence of myocardial infarcts has significantly decreased during the last decade, however, in spite of early reperfusion, loss of functional myocardium leading to subsequent severe cardiac failure still presents a significant medical problem (25). Salvage of additional myocardium is, therefore, a highly desirable aim. Several recent studies have indicated that hyperthermic treatment of rats or rabbits results in signifcantly improved myocardial salvage after coronary occlusion and reperfusion $(11,26,27)$. Hyperthermic treatment results in increased levels of the inducible HSP70 protein but because several other alterations like increases in catalase levels and ATP alterations (4), in addition to changes in other heat shock proteins also occur, it is currently unclear if increased HSP70 protein levels by themselves can lead to protection against ischemia-related damage. A protective role for increased expression of HSP70 proteins has been demonstrated against lethal heat shock in a rat fibroblast cell line (9) and in simian CV cells (10). These studies indicate that the presence of the HSP70 protein before a lethal heat shock maybe one of the main causes for the protection seen during thermotolerance. The phenomenon of thermotolerance has been thought to be mediated through the increase of expression of heat shock proteins, especially that of the HSP70, the most abundant of the HSPs. Specific aspects of cell damage are, however, quite different for different noxious stimuli. For example, heating of fibroblasts leads to a rapid collapse of intermediate filaments (28), whereas exposure of heart-derived cells to ischemia-like conditions preferentially effects the integrity of the cell membrane or sarcolemma (29). In addition, in heated hearts ATP levels increase (4), whereas in ischemia exposed hearts ATP levels are markedly decreased (30). Demonstration of a protective effect of HSP70 against thermal stress induced damage in nonmuscle cells can, therefore, not be extrapolated to a protective role of HSP70 against ischemia-related damage in heart-derived myocytic cells.

Therefore, our aim in this study was to determine if increased expression of inducible HSP70 protein in rat heart derived $\mathrm{H} 9 \mathrm{c} 2$ cells could exert a protective effect against injury induced by ischemia-like conditions. In initial studies, we determined if the protective effect induced by a heat shock could be translated into a protective effect against an ischemic-like stress. We submitted the myogenic $\mathrm{H} 9 \mathrm{c} 2$ cells to a brief heat treatment $\left(42^{\circ} \mathrm{C}, 30 \mathrm{~min}\right)$, allowed them to recover for $8 \mathrm{~h}$, and subsequently submitted them to our experimental simulated ischemic conditions. This preconditioning of the H9c2 cells markedly increased the expression of the inducible HSP70 at the mRNA and protein level (Fig. 3) and was found to render the cells markedly resistant to an ischemic stress (Figs. 1 and 2).

To investigate the role of inducible HSP70 in transmitting protection against ischemic damage in further detail, we generated a stably transfected $\mathrm{H} 9 \mathrm{c} 2(2-1)$ single-cell derived clonal cell line that overexpresses significant amounts of the exogenous hHSP70 gene at both the mRNA and protein level (Figs. 4 and 5). As previously observed by other investigators, we found that pooled stably transfected cell lines for the hHSP70 expressed insignificant amounts of the exogenous HSP70. In addition, the majority of the single-cell derived clonal cell lines express either limited amounts of HSP70 or none (Figs. 4 and 5 ). The probable reason for the low frequency of stable lines that consistently overexpress the exogenous HSP70 gene under normal conditions seems to relate to the effect increased HSP70 expression has on cell growth. A recent study in Drosophila cells has shown that when the cell is forced to express large amounts of the inducible form of the HSP70 gene, cell growth is compromised (31). As a consequence of the prolonged maintenance of the stable cell line in culture, cells overexpressing HSP70 probably are overrun because of their slower growth rate by faster growing cells that do not constitutively express the inducible form of HSP70. Our H9/hHSP70/1 was also found to have a slower growth rate especially at very low passage number (one to three passages after being thawed out) than the average pool of parental $\mathrm{H} 9 \mathrm{c} 2(2-1)$ or the $\mathrm{H} 9 / \mathrm{NEO}$ cell line. For this reason, all experiments were carried out with H9/hHSP70/ 1 at low passage number (between 3 and 10 pas-

\footnotetext{
Figure 6. Immunohistochemistry of H9c2(2-1) cells stably transfected with human HSP70i under the control of the SV40 enhancer. Cells were fixed and reacted with a monoclonal antibody that binds to the inducible HSP70 and developed with a Vectastain ABC kit. $(A)$ Stably transfected H9c2 (2-1) cells (clonal line H9/hHSP70/1) overexpressing the human HSP70i (brown coloration) under nonstress conditions. The exogenous HSP70i is evenly distributed through the cell in the absence of stress. (B) Stably transfected H9c2(2-1) cells (clonal line H9/hHSP70/1) that have been heat shocked $\left(42^{\circ} \mathrm{C}, 60 \mathrm{~min}\right)$ and left to recover for $2 \mathrm{~h}$ at $37^{\circ} \mathrm{C}$. Most of the exogenous, as well as the endogenous rHSP70i, is localized in the nucleus of the cells (brown coloration). $(C) \mathrm{H} 9 \mathrm{c} 2(2-1)$ cells that have not been stressed show absence of any HSP70i. (D) Heatshocked H9c2 (2-1) cells show the appearance of the inducible endogenous rat HSP70 (brown coloration), which is mostly localized in and around the nucleus.
} 

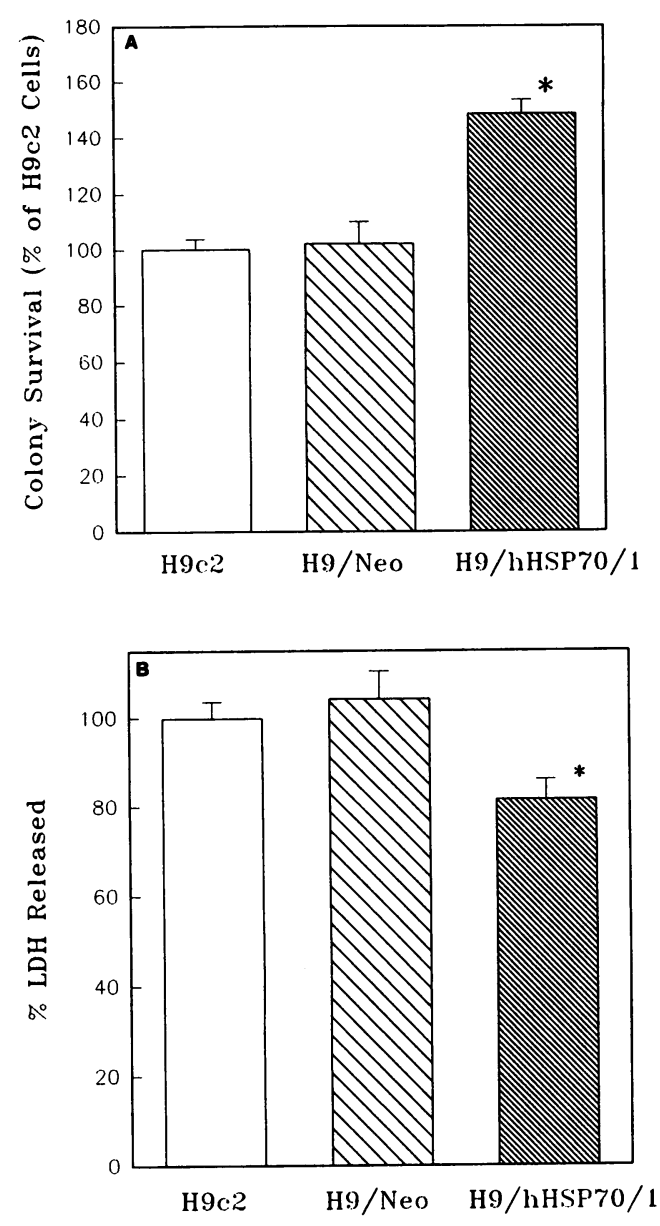

Figure 7. Cell injury in stably transfected H9c2(2-1) cell lines after simulated ischemia. $(A)$ Colony survival assay of $\mathrm{H} 9 \mathrm{c} 2(2-1)$ cells and stably transfected cell lines H9/NEO (neomycin expression vector only containing cell line) and H9/hHSP70/1 (human HSP70 overexpressing cell line) after simulated ischemia. Cells were subsequently trypsinized, replated at low density, and cultured for 7-9 d. The number of surviving colonies from each group was normalized to untreated H9c2(2-1) cells. $\square, \mathrm{H} 9 \mathrm{c} 2(2-1)$ cells submitted to simulated ischemia and taken as $100 \%$ of possible surviving colonies; $\mathbb{\$}, \mathrm{H} 9 / \mathrm{NEO}$ clonal cell line; $\mathbb{\mathbb { N }}$, H9/hHSP70/1 clonal cell line surviving colonies after simulated ischemia. Results are from six independent experiments $(* P<0.05)$. (B) LDH release in $\mathrm{H} 9 \mathrm{c} 2(2-1)$ cells and stably transfected cell lines $\mathrm{H} 9 /$ $\mathrm{NEO}$ and H9/hHSP70/1 after simulated ischemia. Results are expressed as percentage of LDH released over total LDH (released + cellular $\mathrm{LDH}$ ) for each sample and normalized to the $\mathrm{LDH}$ released by control H9c2 (2-1) cells. $\square, \mathrm{LDH}$ released by H9c2(2-1) cells after simulated ischemia taken as $100 \%$ of possible $\mathrm{LDH}$ release; $\mathbb{\mathbb { N } , \mathrm { LDH }}$ released by the clonal line $\mathrm{H} 9 / \mathrm{NEO}$; $\mathbb{\mathrm { L }} \mathrm{LDH}$ released by the $\mathrm{H} 9$ / hHSP70/1 cell line after simulated ischemia.

sages) and was paired in the experiments with $\mathrm{H} 9 / \mathrm{NEO}$ and $\mathrm{H} 9 \mathrm{c} 2(2-1)$ cells of similar passage number and growth rate. Immunohistochemistry done on the clonal line H9/hHSP70/ 1 shows that under nonstress conditions, the hHSP70 is distributed mainly in the cytoplasm of these cells. Upon heat shock, the exogenous hHSP70 relocalizes to and around the nucleus (Fig. 6). This implies that the human HSP70 behaves as the endogenous rat HSP70 and most probably is a functional HSP70.

Our results show that the cell line H9/hHSP70/ 1 exhibits a significant increase in cell survival as measured by the colony survival assay and a marked resistance to cellular injury as measured by $\mathrm{LDH}$ release into the medium after ischemic stress (Fig. 7). This indicates that part or most of the protection conferred by a pre-heat treatment against a subsequent ischemic-like stress is attributable to the increased presence of the inducible HSP70. As indicated above, recent results in rats and rabbits has shown that a whole body heat treatment confers a protective effect against ischemic damage in vivo $(11,26,27)$. Our studies in the myogenic H9c2(2-1) cell line would directly implicate the inducible HSP70 as responsible for this protective effect. Evidence that HSP70 plays this protective role in vivo, as well as in vitro, is within our present day experimental possibilities. Our laboratory is engaged in the development of in vivo models over-expressing an exogenous HSP70 in the heart of transgenic mice. Such animals will allow us to determine if HSP70 has a protective effect in vivo.

\section{Acknowledgments}

We would like to thank Dr. Don F. Kirksey from Glaxo Inc. (Research Triangle Park, NC) for encouragement during the early stages of this work. We would also like to thank Roslyn Lara for secretarial assistance.

This work was supported by National Institutes of Health grant HL-17682 and an American Heart Association Grant-in-Aid.

\section{References}

1. Dillmann, W. H., H. B. Mehta, A. Barrieux, B. D. Guth, W. E. Neeley, and J. Ross, Jr. 1986. Ischemia of the dog heart induces the appearance of a cardiac mRNA coding for a protein with migration characteristics similar to heat-shock/ stress protein 71. Circ. Res. 59:110-114.

2. Currie, R. W. 1987. Effects of ischemia and perfusion temperature on the synthesis of stress-induced (heat shock) proteins in isolated and perfused rat hearts. J. Mol. Cell. Cardiol. 19:795-808.

3. Mehta, H. B., B. K. Popovich, and W. H. Dillmann. 1988. Ischemia induces changes in the level of $\mathrm{mRNAs}$ coding for stress protein 71 and creatine kinase M. Circ. Res. 63:512-517.

4. Currie, R. W., M. Karmazyn, M. Kloc, and K. Mailer. 1988. Heat-shock response is associated with enhanced postischemic ventricular recovery. Circ. Res. 63:543-549.

5. Deshaies, R. J., B. D. Koch, M. Werner-Washburne, E. A. Craig, and R. Schekman. 1988. A subfamily of stress proteins facilitates translocation of secretory and mitochondrial precursor polypeptides. Nature (Lond.). 800-805.

6. Chirico, W. J., M. G. Waters, and G. Blobel. 1988. 70K heat shock related proteins stimulate protein translocation into microsomes. Nature (Lond.). 332:805-810.

7. Riabowol, K. T., L. A. Mizzen, and W. J. Welch. 1988. Heat shock is lethal to fibroblasts microinjected with antibodies against hsp70. Science (Wash. DC). 242:433-436.

8. Johnston, R. N., and B. L. Kucey. 1988. Competitive inhibition of hsp70 gene expression causes thermosensitivity. Science (Wash. DC). 242:1551-1554.

9. Li, G. C., L. Li, Y.-K. Liu, J. Y. Mak, L. Chen, and W. M. F. Lee. 1991. Thermal response of rat fibroblasts stably transfected with the human 70-kD heat shock protein-encoding gene. Proc. Natl. Acad. Sci. USA. 88:1681-1685.

10. Angelidis, C. E., I. Lazaridis, and G. N. Pagoulatos. 1991. Constitutive expression of heat-shock protein 70 in mammalian cells confers thermoresistance. Eur. J. Biochem. 199:35-39.

11. Donnelly, T. J., R. E. Sievers, F. L. J. Vissern, W. J. Welch, and C. L. Wolfe. 1991. Heat shock protein induction in rat hearts. Circulation. 85:769-778.

12. Iwaki, K., S.-H. Chi, W. H. Dillmann, and R. Mestril. 1993. Induction of HSP70 in cultured rat neonatal cardiomyocytes by hypoxia and metabolic stress. Circulation. 87:2023-2032.

13. Hunt, C., and R. I. Morimoto. 1985. Conserved features of eukaryotic hsp70 genes revealed by comparison with the nucleotide sequence of human hsp70. Proc. Natl. Acad. Sci. USA. 82:6455-6459.

14. Seip, W. F., and G. L. Evans. 1980. Atmospheric analysis and redox potentials of culture media in the GasPak system. J. Clin. Microbiol. 11:226-233.

15. Chen, C., and H. Okayama. 1987. High-efficiency transformation of mammalian cells by plasmid DNA. Mol. Cell. Biol. 7:2745-2752.

16. Chomczynski, P., and N. Sacchi. 1987. Single-step method of RNA isolation by acid guanidinium thiocyanate-phenol-chloroform extraction. Anal. Biochem. 162:156-159. 
17. Sambrook, J. E. F., Fritsch, and T. Maniatis. 1989. Analysis of RNA. In Molecular Cloning: A Laboratory Manual. Cold Spring Harbor Laboratory Press, Cold Spring Harbor, NY. pp. 7.43-7.52.

18. Welch, W. J., and J. R. Feramisco. 1985. Rapid purification of mammalian 70,000-dalton stress proteins: affinity of the proteins for nucleotides. $\mathrm{Mol}$ Cell. Biol. 5:1229-1237.

19. Lemasters, J. J., J. DiGuiseppi, A.-L. Nieminen, and B. Herman. 1987. Blebbing, free $\mathrm{Ca}^{2+}$ and mitochondrial membrane potential preceding cell death in hepatocytes. Nature (Lond.). 325:78-81.

20. Summerhayes, I. C., T. J. Lampidis, S. D. Bernal, J. J. Nadakavukaren, K. K. Nadakavukaren, E. L. Shepherd, and L. B. Chen. 1982. Unusual retention of rhodamine 123 by mitochondria in muscle and carcinoma cells. Proc. Natl. Acad. Sci. USA. 79:5292-5296.

21. Velazquez, J. M., and S. Lindquist. 1984. HSP70: nuclear concentrations during environmental stress and cytoplasmic storage during recovery. Cell. 36:655-662.

22. Baler, R., W. J. Welchm, and R. W. Voellmy. 1992. Heat shock gene regulation by nascent polypeptides and denatured proteins: HSP70 as a potential autoregulatory factor. J. Cell Biol. 117:1151-1159.

23. Abravaya, K., M. P. Myers, S. P. Murphy, and R. I. Morimoto. 1992. The human heat shock protein HSP70 interacts with HSF, the transcription factor that regulates heat shock gene expression. Genes Dev. 6:1153-1164.
24. Hickey, E., S. E. Brandon, S. Sadis, G. Smale, and L. A. Weber. 1986. Molecular cloning of sequences encoding the human heat shock proteins and their expression during hyperthermia. Gene. 43:147-154.

25. American Heart Association. 1990 Heart Facts. American Heart Association National Center, Dallas. p. 1.

26. Currie, R. W., R. M. Tanguay, and J. G. Kingma, Jr. 1992. Heat-shock response and limitation of tissue necrosis during occlusion/reperfusion in rabbit hearts. Circulation. 87:963-971.

27. Yellon, D. M., E. Pasini, A. Cargnoni, M. S. Marber, D. S. Latchman, and R. Ferrari. 1992. The protective role of heat stress in the ischaemic and reperfused rabbit myocardium. J. Mol. Cell. Cardiol. 24:895-907.

28. Collier, N. C., and M. J. Schlesinger. 1986. The dynamic state of heat shock proteins in chicken embryo fibroblasts. J. Cell Biol. 103:1495-1507.

29. Jennings, R. B., K. A. Reimer, C. Steenbergen, Jr. 1986. Myocardial ischemia revised. The osmolar load, membrane damage, and reperfusion. J. Mol. Cell. Cardiol. 18:769-780.

30. Jennings, R. B., H. K. Hawkins, J. E. Lowe, M. L. Hill, S. Klotman, and K. A. Reimer. 1978. Relation between high energy phosphate and lethal injury in myocardial ischemia in the dog. Am. J. Pathol. 92:187-214.

31. Feder, J. H., J. M. Rossi, J. Solomon, N. Solomon, and S. Lindquist. 1992. The consequences of expressing hsp70 in Drosophila cells at normal temperatures. Genes Dev. 6:1402-1413. 